\title{
Vertebral Body Reconstruction using Expandable Titanium Cages after Anterior Decompression for Cervical Spondylotic Myelopathy: A Review
}

\author{
Ahmed J. Awad ${ }^{1}$, David A. Stidd ${ }^{2}$, Kenan Alkhalili ${ }^{3}$, Ilyas M. Eli ${ }^{4}$, Ali A. Baaj ${ }^{2}$ \\ 1. Faculty of Medicine and Health Sciences, An-Najah National University, Nablus, Palestine 2. Division \\ of Neurosurgery, University of Arizona, Tucson, AZ 3. Cairo University School of Medicine, Cairo, Egypt \\ 4. Vanderbilt University School of Medicine, Vanderbilt University School of Medicine
}

$\square$ Corresponding author: Ahmed J. Awad,dr_ahmedja@hotmail.com

Disclosures can be found in Additional Information at the end of the article

\section{Abstract}

Objective: Cervical spondylotic myelopathy is a progressive debilitating disease that favorably responds to surgical decompression. The objective of this study was to review the use of expandable titanium cages for reconstruction of the spine after cervical corpectomy.

Methods: We searched PubMed and Google Scholar databases up to March 2013 to identify English articles reporting the use of expandable titanium cages in cervical spondylotic myelopathy (CSM). Identified articles were excluded if they lacked CSM cases, radiologic or clinical outcomes were not reported, and if only static cages cases were reported. Additional relevant references from these articles were also reviewed.

Results: A total of six case series published from 2005 through 2012 with a combined total of 143 patients who underwent implantation of an expandable titanium cage and a mean followup of 21.4 months were identified and included for review. The combined fusion rate was $97 \%$, and the mean correction of cervical lordosis reported for 125 patients was $10.1^{\circ}$. The combined complication rate was $10 \%$, and the overall reported outcomes were favorable.

Conclusions: The results of this review demonstrate that the use of expandable titanium cages is safe and effective after decompression in the treatment of cervical spondylotic myelopathy. The features of the expandable titanium cages allow for easier incorporation of the cage into a corpectomy defect relative to a static titanium mesh cage, adding structural support and restoring sagittal alignment.

Received 03/05/2014 Review began 03/06/2014 Review ended 03/22/2014 Published 03/23/2014

\section{C) Copyright 2014}

Awad et al. This is an open access article distributed under the terms of the Creative Commons Attribution License CC-BY 3.0., which permits unrestricted use, distribution, and reproduction in any medium, provided the original author and source are credited.
Categories: General Surgery, Neurosurgery

Keywords: cervical spondylotic myelopathy, corpectomy, expandable cage, spinal fusion, subsidence

\section{Introduction And Background}

Cervical spondylotic myelopathy (CSM) is a progressive degenerative process of the cervical spine resulting in narrowing of the spinal canal, causing a variety of nonspecific clinical symptoms that make early diagnosis challenging. The overall prevalence of CSM is unknown, but CSM is the most common cause of myelopathy in adults over 55 years of age and causes progressive disability [1-2]. The clinical presentation is insidious and varies, but subtle gait 
spasticity is a common initial symptom followed by upper extremity paresthesia and loss of dexterity [2-3]. A high degree of clinical suspicion is needed to make an early diagnosis, and unlike other pathologies of the spine, multiple studies have shown progressive neurologic deterioration in up to two-thirds of patients with CSM treated with medical management alone [2]. Response to surgical decompression and stabilization has been correlated with duration of symptoms prior to intervention, and multiple studies suggest that prognosis improves after surgical intervention if the duration of symptoms is less than one year [4-6]. Diabetes is the most frequent morbidity having the most significant impact on surgical results [7]. Moreover, in CSM patients following multilevel decompression with bone grafting, the rate of solid osseous union is higher in non-smokers than smokers [8].

The main surgical objective for CSM is decompression of the neural elements of the cervical spine. Other goals of surgery include restoration of height, sagittal alignment, and structural stability. The means to these objectives are varied and debated. Studies have failed to reproducibly demonstrate improved outcomes for any one surgical approach over another [910], and thus, specific surgical approaches are subject to surgeon preference. There are, however, guiding principles to help determine whether a ventral versus a dorsal approach to the cervical spine is optimal. A laminectomy via a dorsal approach, for example, is most appropriate for pathologies compressing the dorsal surface of the spinal cord, such as buckling of the ligamentum flavum or facet arthropathy. Ventral decompressions are most suited for anterior pathologies, including disc herniation or osteophytic complexes compressing the ventral spinal cord. Sagittal alignment is also an important characteristic to consider when determining surgical approach. For instance, dorsal approaches have been associated with poor outcomes for patients with cervical kyphosis [11].

Dynamic expandable titanium cages have increasingly been used within the past decade to reconstruct the cervical spine after decompressive corpectomies (Figure 1). These new cages are more versatile than static mesh cages, and the new cages can be expanded in situ within a corpectomy defect, restoring sagittal alignment in a controlled manner [12]. Expandable cages, however, are not without associated complications, such as subsidence, instrumentation failure, and adjacent vertebral body fractures [13]. In this paper, we review the current use of expandable titanium cages for spinal reconstruction after ventral decompression of CSM patients. 


\section{Cureus}

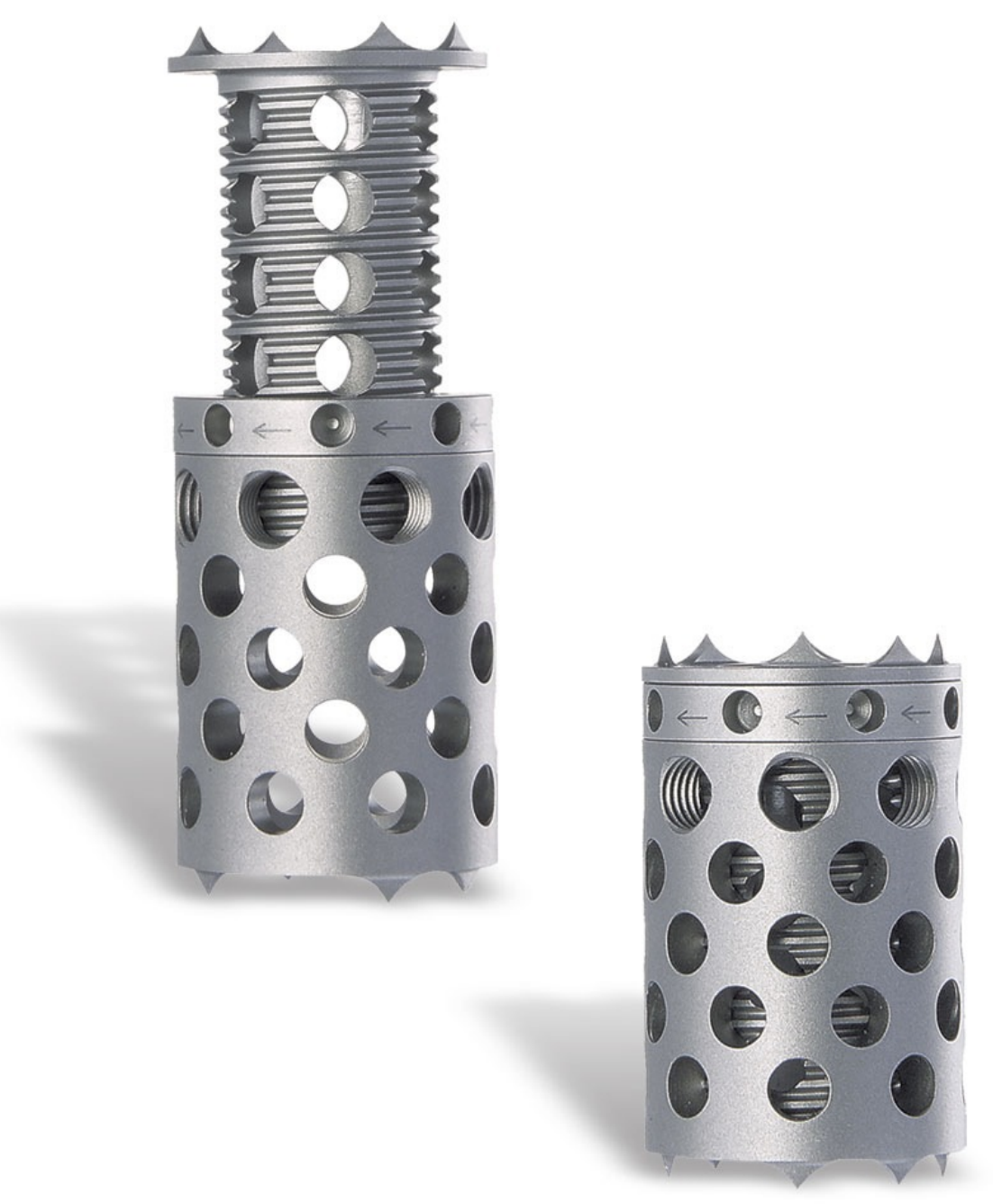

FIGURE 1: The VBR cage (Ulrich, Ulm, Germany) expandable titanium cage. (Courtesy of Ulrich Medical)

\section{Review}

\section{Methods}

The PubMed and Google Scholar databases were queried to identify English articles reporting the use of expandable titanium cages in cervical spine surgery. We searched the databases up to March 2013. Identified articles were excluded if they lacked CSM cases, radiologic or clinical outcomes were not reported, only static cages cases were reported, and if the CSM patients couldn't be distinguished from patients with other diagnoses. Cross check of reference lists from identified articles was performed for additional information.

\section{Results}

A total of six case series published from 2005 through 2012 were identified and included for review (Table 1). Of the six case series, there were five retrospective [12, 14-18] and one prospective observational [19] study. A combined total of 143 patients underwent cervical spine reconstruction using expandable titanium cages after corpectomies with a combined mean 


\section{Cureus}

follow-up of 21.4 months. The mean age of the patients at the time of surgery was 59 . Treated pathologies were restricted to cervical spondylotic myelopathy. A variety of expandable titanium cages were implanted: ADD (Ulrich, Ulm, Germany) [12, 14, 16, 19], ADDPlus (Ulrich, Ulm, Germany) [12, 14], VBR (Ulrich, Ulm, Germany) [17], Synex ECC (Synthese Spine, West Chester, PA) [15], and Tecorp (Scient'x, France) [18]. Correction of sagittal balance was reported for 130 patients, and the combined mean lordotic correction was $10.1^{\circ}$. Anterior cervical plating and/or posterior lateral mass/pedicle screw fixation have been used. In all cases treated with ADD, Tecorp, and Synex, anterior plating has been used. This would include all of the patients reviewed with the exception of 28 patients from Cabraja, et al. study and an unknown number in the Woiciechowsky, et al. study. ADDPlus cage, which has attached plate with two holes for screw fixation on both sides, has been used for those patients [12, 14]. In the ADD group, two different plate types were used, a semi-constrained plate and a dynamic plate. 


\section{Cureus}

\begin{tabular}{|c|c|c|c|c|c|c|c|c|c|c|c|c|}
\hline \multirow[b]{2}{*}{ Study } & \multirow{2}{*}{$\begin{array}{l}\text { No. of } \\
\text { csM } \\
\text { cases }\end{array}$} & \multirow[b]{2}{*}{$\begin{array}{l}\text { Age } \\
(\mathrm{m} / \mathrm{f})\end{array}$} & \multirow{2}{*}{$\begin{array}{l}\text { Mean } \\
\text { Follow } \\
\text { Up } \\
\text { (mo.) }\end{array}$} & \multirow{2}{*}{$\begin{array}{l}\text { Mean } \\
\text { Lordotic } \\
\text { Correction }\end{array}$} & \multirow[b]{2}{*}{$\begin{array}{l}\text { Fusion } \\
\text { Rate }\end{array}$} & \multirow{2}{*}{$\begin{array}{l}\text { Mean } \\
\text { Subsidence } \\
(\mathrm{mm})\end{array}$} & \multirow{2}{*}{$\begin{array}{l}\text { Cases } \\
\text { with } \\
\text { Dorsal } \\
\text { Fixation }\end{array}$} & \multirow[b]{2}{*}{ Complications } & \multicolumn{4}{|l|}{ Outcome } \\
\hline & & & & & & & & & $\begin{array}{l}\text { VAS } \\
\text { Decrease }\end{array}$ & $\begin{array}{l}\text { Nurick } \\
\text { Grade } \\
\text { Decrease }\end{array}$ & $\begin{array}{l}\text { mJOA } \\
\text { Increase }\end{array}$ & $\begin{array}{l}\text { Odom } \\
\text { Criteria }\end{array}$ \\
\hline $\begin{array}{l}\text { Woiciechowsky } \\
\text { (2005) }\end{array}$ & 13 & 60 & 34 & & $100 \%$ & 1 case & 0 & & & & & $\begin{array}{l}55 \% \\
\text { excellent } \\
20 \% \text { good, } \\
15 \% \\
\text { satisfactory, } \\
\text { and } 10 \% \\
\text { poor. }\end{array}$ \\
\hline Auguste (2006) & 16 & $\begin{array}{l}50.5 \\
8 / 8\end{array}$ & 22 & $22^{\circ *}$ & $100 \%$ & $\begin{array}{l}2.3 \mathrm{~mm} \text { for } 1-\mid \mathrm{vl} \\
1.8 \mathrm{~mm} \text { for } 2-\mid \mathrm{vl} \\
6.5 \mathrm{~mm} \text { for } 3-\mathrm{Ivl}\end{array}$ & 16 & 3 transient dysphagia & 4.08 & 1.0 & & \\
\hline Payer (2006) & 20 & $\begin{array}{l}55 \\
13 / 7\end{array}$ & 14 & $8^{\circ}$ & $95 \%$ & & 5 & $\begin{array}{l}1 \text { transient C5 palsy, } 1 \text { transient } \\
\text { RLN palsy, } 1 \text { persistent } \\
\text { dysphagia }\end{array}$ & 1.3 & & & \\
\hline $\begin{array}{l}\text { Cabraja (March } \\
\text { 2010) }\end{array}$ & 24 & $\begin{array}{l}60.4 \\
12 / 12\end{array}$ & 35 & $8.8^{\circ}$ & $100 \%$ & & 0 & $\begin{array}{l}1 \text { screw loosening, } 1 \text { screw } \\
\text { break, } 1 \text { adjacent level disease } \\
\text { requiring dorsal fixation }\end{array}$ & 1.5 & & 3.3 & \\
\hline $\begin{array}{l}\text { Cabraja (May } \\
\text { 2010) }\end{array}$ & 44 & $\begin{array}{l}63 \\
28 / 16\end{array}$ & 12 & $4.4^{\circ}$ & $\begin{array}{l}100 \% \text { cage } \\
\text { +plate } 89 \% \\
\text { winged } \\
\text { cage }\end{array}$ & $\begin{array}{l}0.96 \text { cage + } \\
\text { plate } 0.91 \\
\text { winged cage } \\
\text { (ratios) }\end{array}$ & $\begin{array}{l}0 \text { at } 1^{\text {st }} \\
\text { surgery, } \\
3 \text { at } \\
\text { revision }\end{array}$ & $\begin{array}{l}3 \text { cases of neurological decline } \\
\text { and increased neck pain }\end{array}$ & & & & $\begin{array}{l}26 \text { excellent } \\
10 \text { good } 5 \\
\text { fair } 3 \text { poor }\end{array}$ \\
\hline Zairi (2012) & 26 & $\begin{array}{l}60 \\
14 / 12\end{array}$ & 24 & $15^{\circ}$ & $100 \%$ & & 0 & $\begin{array}{l}1 \text { transient dysphagia, } 1 \text { cage } \\
\text { migration requiring reoperation } \\
\text { with persistent arm weakness }\end{array}$ & 2.5 & & & \\
\hline Average & & & 59 & & & $97 \%$ & & & & 2.2 & & \\
\hline Total & 143 & & & & & & & 24 & & & & \\
\hline
\end{tabular}

TABLE 1: Summary of Reported Expandable Titanium Cages for Cervical Spine

\section{Reconstruction After Corpectomy}

*For 7 patients with preexisting kyphosis

The combined fusion rate reported was $97 \%$. Each series defined fusion as the absence of movement on flexion and extension radiographs [12, 14-19] or the absence of implant-endplate interface lucency on computed tomographic scans [12, 14, 16-17, 19]. Woiciechowsky further characterized the bony mass within the cages as a measure of Hounsfield units [14]. Fusion was evaluated on flexion-extension radiographs at six, 12, or 24 months [12, 14, 16-19]. The expandable cages were packed with local autograft harvested from the index vertebral bodies or 
with $\beta$-tricalcium phosphate (TCP) prior to implantation. Of the patients with reported data regarding dorsal fixation, in addition to the ventral titanium cage implant, only $17 \%$ of the patients underwent dorsal instrumentation to augment the ventral construct at the initial decompressive operation.

The combined complication rate of the 143 reported cases was 10\%. One patient experienced persistent right arm weakness after an implanted cage migrated and required a reoperation [18], and one patient suffered from persistent dysphagia [19]. One patient developed adjacent level disease, which later required dorsal fixation to augment the anterior column [16]. Otherwise, the remaining morbidities were transient and consisted of five cases of dysphagia, one C5 nerve palsy, two recurrent laryngeal nerve palsies, one retropharyngeal hematoma, and screw failure that did not compromise fusion.

The overall outcome of the case series was favorable. The combined mean visual analogue score (VAS) reported for 86 patients decreased by 2.2 points. Auguste, et al. reported a mean decrease of 1.0 points of the Nurick grade for 16 CSM patients [15], and Cabraja, et al. reported an increase of 3.3 points of the modified Japanese Orthopedic Association (mJOA) scale for 24 patients [16]. Both Woiciechowsky and Cabraja, et al. reported overall generally favorable outcomes for 55 patients using the Odom Criteria [12, 14].

\section{Discussion}

Since the introduction of the anterior cervical discectomy in 1958 [20], anterior approaches for cervical decompression and stabilization have evolved technically from a single-level anterior decompression of a disc to multilevel corpectomies with expanding indications, including the treatment of CSM. Cervical corpectomy is a versatile procedure for anterior decompression of the spinal cord. Traditionally, autologous tricortical iliac bone has been considered the "gold standard" for reconstructing the anterior column after bone removal, but donor site morbidity, pseudarthrosis, and graft displacement have historically been complicating problems [21-24]. Allograft bone obviates the donor site morbidity of autograft iliac bone, but fusion rates for allograft relative to autograft have not been as high [25-26].

Titanium mesh cages have provided a significant improvement for cervical fusion and reconstruction. The mesh cage can be packed with local autograft harvested from the corpectomy surgery and provides structural support restoring physiologic height. Autologous bone grafts proved to improve fusion rates in patients in whom they are used. An, et al. reported that pseudarthrosis developed in $46.2 \%$ of patients who underwent fusion with allograft demineralized bone matrix, whereas pseudarthrosis occurred in $26.3 \%$ in whom autograft-assisted fusion was performed [27]. Moreover, TCP shows excellent bone formation at early time points with no material-related adverse effects [28]. The use of TCP makes the bone ingrowth possible despite the small central cavity [14]. Consequently, fusion rates evaluated on flexion-extension radiographs at six, 12, or 24 months have been reported as 97 to $100 \%$ [12, 14, 16-19].

Mesh cages have several disadvantages, however. The mesh cages are technically challenging to implant. The length of the cage must be precisely cut to the length of the corpectomy defect. A mesh cage cut too long causes overdistraction of the cervical level and may result in traction injury to the exiting spinal nerves or adds excessive pressure to the adjacent endplates, increasing the risk of subsidence [29]. Alternatively, a titanium mesh cage too short results in weak compression at the endplate interface and may cause cage migration [14]. Impacting a mesh cage into position over the cervical spinal cord risks injury to the cord and may damage the adjacent endplates causing subsequent subsidence. 


\section{Cureus}

Expandable titanium cages are more versatile than static mesh cages, allowing for easier implantation of the cage into a corpectomy defect (Figure 2). The expansion mechanism allows for precise, controlled expansion of the cage in situ with adequate compression at the endplate interfaces and avoiding overdistraction [12, 14, 19]. Care, however, must be taken during cage expansion since the expansion torque has been shown to poorly correlate with endplate forces [30]. The results of this review demonstrate an excellent overall fusion rate of $98 \%$ for expandable titanium cages, a comparable value to the fusion rate of static mesh cages. Less time is required to implant expandable cages relative to mesh cages, which in turn decreased perioperative morbidities, including transient dysphagia. 


\section{Cureus}

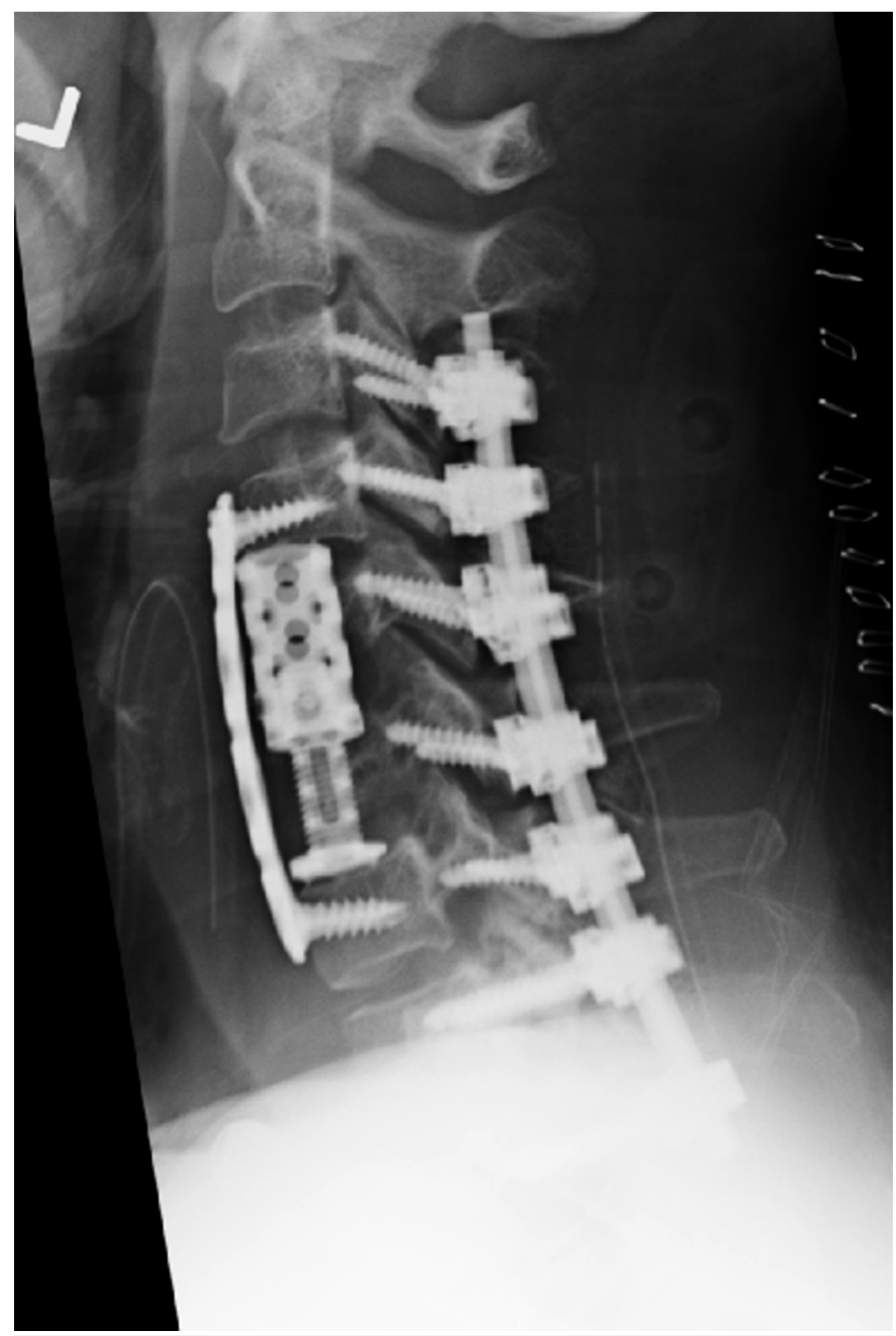

FIGURE 2: Postoperative lateral radiograph of a VBR cage cervical spine reconstruction after decompressive C5 and C6 corpectomies augmented with $\mathrm{C} 3$ - T1 dorsal fixation. 
Expandable cages have associated complications. There is some evidence to suggest that despite the greater surface contact area, expandable cages have a trend for higher subsidence rates when compared to fixed cages [31-32]. Some biomechanical assessments of expandable cages suggest associated higher subsidence rates and intraoperative fractures during deployment [30-31]. Contrary to this, other biomechanical studies indicate expandable titanium cages are biomechanically equivalent to other cages and autologous iliac crest bone graft [33-36]. Expandable cages have a smaller central cavity which accommodates less local autograft, and occupy more endplate surface area that would otherwise be available as a fusion surface [17]. Cabraja, et al. demonstrated that expandable cages with fixation wings that avoid the need of anterior plating carried a higher risk of non-fusion and loss of lordotic correction [12]. The overall complication rate of expandable cage implantation reported in six case series of this review was $10 \%$. The indications for the corpectomies vary and include cervical spine tumors which carry a known higher complication rate for surgery. Thus, the complication rate for decompressive corpectomy and reconstruction with an expandable titanium cage for CSM is likely lower.

Interestingly, dynamic plate designs provided a faster fusion of the cervical spine compared with constrained plate designs [37]. In addition, the rate of implant complications is lower within the group of patients receiving a dynamic plate [37]. A less effective load sharing of constrained plates compared with dynamic plates might explain the screw breakage and loosening in the patient in our review.

In summary, the results of this review show promising results from the use of expandable titanium cages for reconstruction of the cervical spine after decompressive cervical corpectomy. The combined fusion rate, lordotic correction, and general outcomes of the surgeries were very comparable to static mesh cages. The complication rate of the procedure as an indication for treating CSM is less than 10\%. Further studies are warranted to investigate the conflicting data regarding biomechanical efficacy of the expandable cages.

\section{Conclusions}

The results of this review demonstrate that expandable titanium cages are safe and effective in the treatment of cervical spondylotic myelopathy. The features of the expandable titanium cage allow for easier incorporation of the cage into a corpectomy defect relative to a static titanium mesh cage, adding structural support and restoring sagittal alignment.

\section{Additional Information}

\section{Disclosures}

Conflicts of interest: In compliance with the ICMJE uniform disclosure form, all authors declare the following: Payment/services info: All authors have declared that no financial support was received from any organization for the submitted work. Financial relationships: Ali A. Baaj declare(s) an alternate financial activity from Royalties. Thieme Medical Publishers. Other relationships: All authors have declared that there are no other relationships or activities that could appear to have influenced the submitted work.

\section{References}

1. Moore AP, Blumhardt LD: A prospective survey of the causes of non-traumatic spastic paraparesis and tetraparesis in 585 patients. Spinal Cord. 1997, 35:361-367.

2. McCormick WE, Steinmetz MP, Benzel EC: Cervical spondylotic myelopathy: Make the difficult diagnosis, then refer for surgery. Cleve Clin J Med. 2003, 70:899-904.

3. Gorter K: Influence of laminectomy on the course of cervical myelopathy . Acta Neurochir (Wien). 1976, 33:265-281. 
4. Montgomery DM, Brower RS: Cervical spondylotic myelopathy. Clinical syndrome and natural history. Orthop Clin North Am. 1992, 23:487-493.

5. Phillips DG: Surgical treatment of myelopathy with cervical spondylosis . J Neurol Neurosurg Psychiat. 1973, 36:879-884.

6. Ebersold MJ, Pare MC, Quast LM: Surgical treatment for cervical spondylitic myelopathy. J Neurosurg. 1995, 82:745-751.

7. Tetreault LA, Nouri A, Singh A, Fawcett M, Fehlings MG: Predictors of Outcome in Patients with Cervical Spondylotic Myelopathy undergoing Surgical Treatment: A Survey of Members from AOSpine International. World Neurosurg. 2013, Epub ahead of print:S1878-8750. 10.1016/j.wneu.2013.09.023

8. Hilibrand AS, Fye MA, Emery SE, Palumbo MA, Bohlman HH: Impact of smoking on the outcome of anterior cervical arthrodesis with interbody or strut-grafting. J Bone Joint Surg Am. 2001, 83-A:668-673.

9. Hukuda S, Mochizuki T, Ogata M, Shichikawa K, Shimomura Y: Operations for cervical spondylotic myelopathy. A comparison of the results of anterior and posterior procedures. J Bone Joint Surg Br. 1985, 67:609-615.

10. Carol MP, Ducker TB: Cervical spondylitic myelopathies: Surgical treatment. J Spinal Disord. 1988, 1:59-65.

11. Batzdorf U, Batzdorff A: Analysis of cervical spine curvature in patients with cervical spondylosis. Neurosurg. 1988, 22:827-836.

12. Cabraja M, Abbushi A, Kroppenstedt S, Woiciechowsky C: Cages with fixation wings versus cages plus plating for cervical reconstruction after corpectomy - is there any difference?. Cent Eur Neurosurg. 2010, 71:59-63.

13. Chou D, Lu DC, Weinstein P, Ames CP: Adjacent-level vertebral body fractures after expandable cage reconstruction. J Neurosurg Spine. 2008, 8:584-588.

14. Woiciechowsky C: Distractable vertebral cages for reconstruction after cervical corpectomy . Spine (Phila Pa 1976). 2005, 30:1736-1741.

15. Auguste KI, Chin C, Acosta FL, Ames CP: Expandable cylindrical cages in the cervical spine: A review of 22 cases. J Neurosurg Spine. 2006, 4:285-291.

16. Cabraja M, Abbushi A, Koeppen D, Kroppenstedt S, Woiciechowsky C: Comparison between anterior and posterior decompression with instrumentation for cervical spondylotic myelopathy: sagittal alignment and clinical outcome. Neurosurg Focus. 2010, 28:E15.

17. Burkett CJ, Baaj AA, Dakwar E, Uribe JS: Use of titanium expandable vertebral cages in cervical corpectomy. J Clin Neurosci. 2012, 19:402-405.

18. Zairi F, Aboukais R, Thines L, Allaoui M, Assaker R: Relevance of expandable titanium cage for the treatment of cervical spondylotic myelopathy. Eur Spine J. 2012, 21:1545-1550.

19. Payer M: Implantation of a distractible titanium cage after cervical corpectomy: technical experience in 20 consecutive cases. Acta Neurochir (Wien). 2006, 148:1173-1180.

20. Cloward RB: The anterior approach for removal of ruptured cervical disks . J Neurosurg. 1958, 15:602-617.

21. Eleraky MA, Llanos C, Sonntag VK: Cervical corpectomy: Report of 185 cases and review of the literature. J Neurosurg. 1999, 90:35-41.

22. Kalfas IH: Role of corpectomy in cervical spondylosis. Neurosurg Focus. 2002, 12:E11.

23. Schnee CL, Freese A, Weil RJ, Marcotte PJ: Analysis of harvest morbidity and radiographic outcome using autograft for anterior cervical fusion. Spine (Phila Pa 1976). 1997, 22 :22222227.

24. Wang JC, Hart RA, Emery SE, Bohlman HH: Graft migration or displacement after multilevel cervical corpectomy and strut grafting. Spine (Phila Pa 1976). 2003, 28:1016-1022.

25. Zdeblick TA, Ducker TB: The use of freeze-dried allograft bone for anterior cervical fusions . Spine (Phila Pa 1976). 1991, 16:726-729.

26. Buttermann GR, Glazer PA, Bradford DS: The use of bone allografts in the spine . Clin Orthop Relat Res. 1996, March:75-85.

27. An HS, Simpson JM, Glover JM, Stephany J: Comparison between allograft plus demineralized bone matrix versus autograft in anterior cervical fusion. A prospective multicenter study. Spine. 1995, 20:2211-2216.

28. Sugawara T, Itoh Y, Hirano Y, Higashiyama N, Mizoi K: beta-Tricalcium phosphate promotes bony fusion after anterior cervical discectomy and fusion using titanium cages. Spine. 2011, 36:E1509-1514. 
29. Arts MP, Peul WC: Vertebral body replacement systems with expandable cages in the treatment of various spinal pathologies: A prospectively followed case series of 60 patients. Neurosurg. 2008, 63:537-545.

30. Pekmezci M, Tang JA, Cheng L, Modak A, McClellan RT, Buckley JM, Ames CP: Comparison of expandable and fixed interbody cages in a human cadaver corpectomy model, part I: endplate force characteristics. J Neurosurg Spine. 2012, 17:321-326.

31. Pekmezci M, Tang JA, Cheng L, Modak A, McClellan RT, Buckley JM, Ames CP: Comparison of Expandable and Fixed Interbody Cages in a Human Cadaver Corpectomy Model: Fatigue Characteristics. J Spinal Disord Tech. . 2012, Aug 23:[Epub ahead of print].

32. Lau D, Song Y, Guan Z, La Marca F, Park P: Radiologic Outcomes of Static Versus Expandable Titanium Cages After Corpectomy: A Retrospective Cohort Analysis of Subsidence. Neurosurg. 2013, 72:529-39. 10.1227/NEU.0b013e318282a558

33. Cardenas RJ, Javalkar V, Patil S, Gonzalez-Cruz J, Ogden A, Mukherjee D, Nanda A: Comparison of allograft bone and titanium cages for vertebral body replacement in the thoracolumbar spine: a biomechanical study. Neurosurg. 2010, 66:314-318.

34. Kandziora F, Pflugmacher R, Schaefer J, Scholz M, Ludwig K, Schleicher P, Haas NP: Biomechanical comparison of expandable cages for vertebral body replacement in the cervical spine. J Neurosurg. 2003, 99:91-97.

35. Khodadadyan-Klostermann C, Schaefer J, Schleicher P, Pflugmacher R, Eindorf T, Haas NP, Kandziora F: Expandable cages: Biomechanical comparison of different cages for ventral spondylodesis in the thoracolumbar spine [Article in German]. Chirurg. 2004, 75:694-701.

36. Pflugmacher R, Schleicher P, Schaefer J, Scholz M, Ludwig K, Khodadadyan-Klostermann C, Haas NP, Kandziora F: Biomechanical comparison of expandable cages for vertebral body replacement in the thoracolumbar spine. Spine (Phila Pa 1976). 2004, 29:1413-1419.

37. Stulik J, Pitzen TR, Chrobok J, Ruffing S, Drumm J, Sova L, Kucera R, Vyskocil T, Steudel WI: Fusion and failure following anterior cervical plating with dynamic or rigid plates: 6-months results of a multi-centric, prospective, randomized, controlled study. Eur Spine J. 2007, 16:1689-94. 